the latest observation near Carseland in 2003,5 the Cattle Egret is still classified as an Accidental/Vagrant species with no documented nesting in the province. ${ }^{3}$ Manitoba's first documented nesting record was 1 September 2005 at Plum Lake, latitude: $49^{\circ} 38^{\prime}$ N. ${ }^{1}$ In Saskatchewan, we now have documented nesting to the west of centre, with a single nest at Goose Lake, latitude: $51^{\circ} 45^{\prime} \mathrm{N}$ and to the east, with a colony at Middle Quill Lake, latitude: $51^{\circ} 56^{\prime} \mathrm{N}$, which is the most northerly documented occurrence of breeding in the prairie region. Further studies and surveys of prairie region wetlands for waterbird nesting will continue to add to our knowledge of the Cattle Egret in our area.

Acknowledgments: Thanks to Bev Gingras, Wendy Calvert, Gillian Turney, Robin Bloom, Martin Schmoll and Lisa Mathias for their perseverance during the long Franklin's Gull surveys in Saskatchewan during which all of these rare sightings were recorded. Review of the manuscript by Wendy Calvert and Ron Bazin provided many helpful improvements.
1. BAZIN, R. 2006. First documented breeding records of Cattle Egrets in Manitoba. Blue Jay 64(3): 126-130.

2. DICKSON, R, A.R. SMITH and P.S. TAYLOR. 2007. Status of wading birds (Ardeids and Ibises) at the north end of Last Mountain Lake in 2006. Blue Jay 65 (2): 67-77.

3. FEDERATION OF ALBERTA NATURALISTS. 2007. The Atlas of Breeding Birds of Alberta: $A$ second look. The Federation of Alberta Naturalists, Edmonton, Alberta. 626 pp.

4. GOLLOP, J.B. 1981. Nesting season. Prairie Provinces region. American Birds 35(6): 950-952.

5. HUDON, J, R. KLAUKE, R. KNAPTON, M.R. LEIN, J. RIDDELL, B. RITCHIE and R. WERSHLER. 2007. Seventh Report of the Alberta Bird Record Committee. Nature Alberta 37 (2): 31-33.

6. HOUSTON, C.S., and M.I. HOUSTON. 1974. The nesting season: June 1, 1974 - July 31, 1974, Northern Great Plains. American Birds 28(5): 915-918.

7. RONEY, K. 1982. Cattle Egret nesting record for Saskatchewan. Blue Jay 40 (3): 163-164.

8. ROY, J.F. 1996. Birds of the Elbow. Special Publication Number 21. Saskatchewan Natural History Society (Nature Saskatchewan). Regina, Saskatchewan. 325 pp.

\title{
FIRST RECORD OF CASSIN'S VIREO FOR SASKATCHEWAN
}

ALAN R. SMITH, Box 154, Avonlea, SK, SOH OC0 and PHILIP S. TAYLOR, Canadian Wildlife Service, 115 Perimeter Road, Saskatoon, SK, S7N 0X4

On 24 May 2002, the first author extracted an unusual bird from one of the 13 mist nets used in migration monitoring studies at the Last Mountain Bird Observatory (LMBO). The bird seemed to be an unusually pale Blueheaded Vireo, features that begged its consideration as a Cassin's Vireo or even a Plumbeous Vireo. As with any capture at $\mathrm{LMBO}$, the bird was taken to the lab, weighed and measured, and given a numbered United States Fish and Wildlife Service aluminum band. As the bird had yet to be identified, Smith called the second author, who was working at Last Mountain Lake National Wildlife Area, to help document and photograph the bird before it was 
released. In all cases but the Alder/ Willow Flycatcher complex, banded birds must be reported as species, not as unidentified birds. Until 1997', this was not a problem for the vireos as the Blue-headed, Cassin's and Plumbeous were considered one species, known as the Solitary Vireo.

During the breeding season, the ranges of the three are as follows. The Blue-headed Vireo, the common species in Saskatchewan, occupies the boreal forest region from southwestern Northwest Territories east to southwestern Newfoundland south through the northeastern United States and the Appalachian Mountains to Georgia. The Cassin's Vireo is found in the Coast Mountains from southwestern British Columbia, south through the western United States to Baja California, and in the Rocky Mountains in southern British Columbia, southwestern Alberta and the northwestern United States. The Plumbeous Vireo, with one sight record for the province, ${ }^{4}$ ranges over the Rocky Mountains from southern Idaho south though the United States and Mexico to Guatemala and El Salvador. ${ }^{1}$

With a slate-blue head, greenish back and yellowish sides, the Blueheaded is the most brightly and boldly coloured of the three. The Plumbeous Vireo sits at the other end of the spectrum, being lead gray above and shading to paler gray below, sometimes with some yellow on its sides. The Cassin's Vireo is intermediate between the two in most characteristics. All three sport wingbars and white spectacles, betraying the common ancestry of the trio. ${ }^{3}$

As the LMBO bird showed a considerable amount of green above and yellow below, the possibility that the bird in question was a Plumbeous
Vireo was soon discounted. The possibility that it was a Cassin's Vireo was, however, less easily dismissed. Heindel (1996) considered the chief differences between the Blue-headed and Cassin's vireos to be the cheek/ throat contrast, head colour, head/back contrast and the amount of white on the outermost tail feathers. Blueheaded Vireos have a blue-gray to gray head contrasting with a white throat, while Cassin's show much less contrast between its gray-green to green head and its off-white throat. The head colour of the Blue-headed Vireo also contrasts strongly with the colour of the back, which is bright green or bright green with gray; again with the Cassin's there is much less contrast between the head and olive back. Finally the Blue-headed has a broader white edging to the outermost tail feathers than the Cassin's. ${ }^{3}$ Buckley noted further that in most or all Blueheaded Vireos, the white edging of the inner vanes usually widens to an upside down "V" at the tip. ${ }^{2}$

The bird captured at LMBO had features consistent with those of Cassin's Vireo. The LMBO bird had a gray green head, showing little contrast with its off-white throat and gray green back. The white edging on the outermost tail feathers was narrow and did not widen to a " $V$ " on the inner vane. Olive-yellow flanks were evident on the bird. These diagnostic field marks can be seen in Figures 1 and 2 on the inside front cover.

The occurrence of Cassin's Vireo is not entirely unexpected as the species breeds in the mountains of southwestern Alberta. Summer sightings of "Solitary Vireos" in the Cypress Hills may also pertain to Cassin's Vireo. Last Mountain Bird Observatory is only $670 \mathrm{~km}$ from the former and $360 \mathrm{~km}$ from the latter. In 
addition, we have recorded other mountain birds at the Observatory, including several each of the Audubon's race of the Yellow-rumped Warbler and MacGillivray's' Warblers.

1. AMERICAN ORNITHOLOGISTS' UNION. 1997. Forty-first Supplement to the American Ornithologists' Union Checklist of North American Birds. The Auk 114: 542-552.
2. BUCKLEY, P.A. 2003. Williamson's Sapsucker, Cordilleran Flycatcher, and other long-distance vagrants at a Long Island, New York stopover site. North American Birds 57: 292-304.

3. HEINDEL, M.T.1996. Field identification of the Solitary Vireo complex. Birding 28: 458:471.

4. TAYLOR, P.S. and R. BISSON. 2006. Plumbeous Vireo sight record for Saskatchewan in 2004. Blue Jay 64:32-34.

\section{UPDATE ON CATTLE EGRET AND WHITE-FACED IBIS BREEDING ACTIVITY AT WHITEWATER LAKE, MB IN 2007}

RON BAZIN, Canadian Wildlife Service, 150 - 123 Main Street, Winnipeg, MB R3C 4W2, E-mail: <ron.bazin@ec.gc.ca>

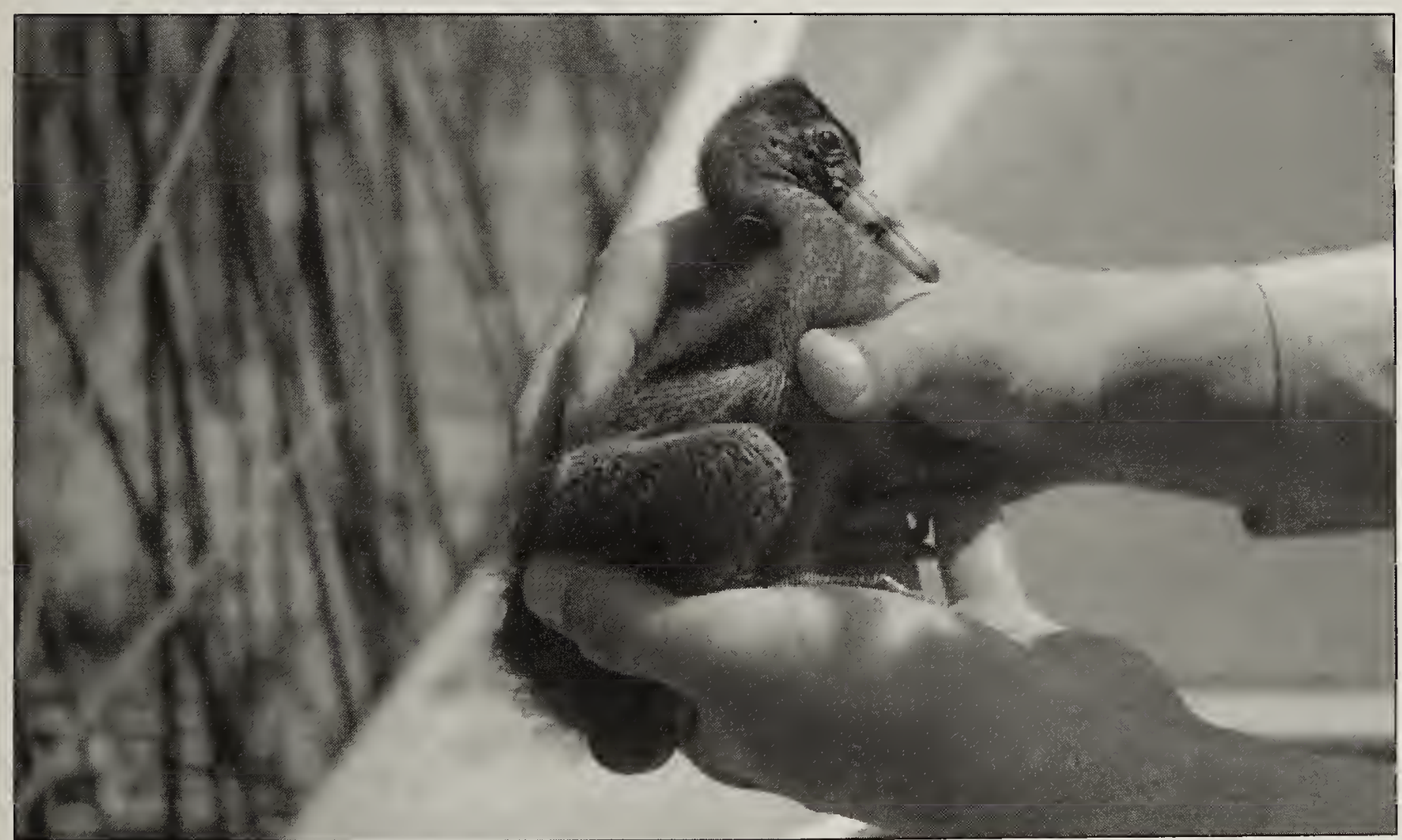

Figure 1. Immature White-faced Ibis at Whitewater Lake, MB on 9 July 2007.

Ron Bazin

Cattle Egrets and White-faced Ibis were observed nesting in Manitoba in 2007, following the first documented successful breeding in 2005 and additional observations in 2006. ${ }^{1,2}$ The 2007 records for both species are from Whitewater Lake, a 9,000 ha saline wetland in southwestern Manitoba between the towns of Boissevain and Deloraine. Whitewater Lake was the location for the first White-faced lbis breeding record in Manitoba in 2005 and the location for several small Cattle Egret colonies in 2006 1,2 . Of particular importance to a number of waterbird species, including Cattle Egrets and 